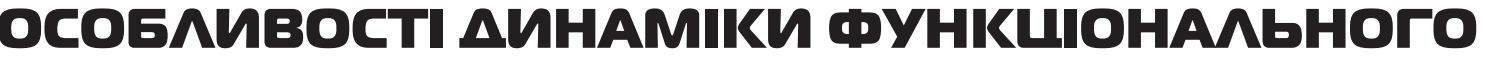 СТАНУ КОМБАТАНTIB З НАСАIАКАМИ БОЙОВОГО СТРЕСУ ЗА ПОКАВНИКАМИ ВАРІАБЕА ВНОСТI СЕРUЕВОГО РИТМУ ВПРОАОВХК КУРСУ KOMN^EKCHOÏ PEAБINTAUII
}

\author{
Зәйиев А. $\mathbf{B}$.
}

\section{Аержавна установа «Інститут медицини праші імені Ю. І. КунАієва Нашіона^ьної академії меАичних наук України», м. Київ}

Bcmyn. Одним з запропонованих методів реабілітації учасників бойових дій є об'ємний пневмопресинг (ОП). Процедура ОП сприяє зростанню активності та зменшенню напруженості регуляторних систем (розвитку автономізації та підвищеного впливу парасимпатичних центрів регуляції), зменшенню серцевого навантаження, відновленню функціонального стану. Однак динаміка стану організму впродовж курсу ОП потребує подальшого вивчення.

Мета дослідження - виявити особливості динаміки функціонального стану комбатантів упродовж курсу комплексної реабілітації, визначити за станом автономної нервової системи строк найбільшої терапевтичної успішності реабілітаційного курсу.

Матеріали та методи дослідження. До дослідження за інформованою згодою залучали учасників бойових дій у зоні проведення АТО/ООС (41 чоловік віком 19-45 років), які отримували курс комплексної реабілітації, зокрема, процедури ОП на зоні голови та спини впродовж 20 хв, у зв'язку з діагностованими розладами адаптації. Запис варіабельності серцевого ритму (ВСР) проводили впродовж 5 хв: 1 раз перед процедурою, 4 рази під час і 1 раз після процедури. Заміри виконували 4 рази (1 доба реабілітаційного курсу, 3-4 доба, 6-7 доба та 10-11 доба). Статистичну обробку виконували методами варіаційної та непараметричної статистики.

Результати. За даними ВСР, для комбатантів з розладами адаптації є характерним стан ваготонії. Упродовж курсу комплексної реабілітації відмічали коливання індексу напруження Баєвського, що характерно для активних адаптаційних процесів. Спостерігали статистично достовірне зміщення вегетативного балансу в бік симпатикотонії, яке можна оцінювати як нормалізацію (компенсацію) функціонального стану. Упродовж реабілітаційного курсу відмічено 44,8 \% випадків нормалізації функціонального стану та 33,4 \% випадків посилення відхилень від меж норми. Динаміка показників за типом нормалізації превалює ( $<<0,05)$. При оцінці реактивності організму комбатантів під дією процедури ОП виявлено, що найбільші короткочасні зміни функціонального стану (максимум адаптаційних реакцій) спостерігалися в період близько 4 доби від початку курсу реабілітації $(\mathrm{p}<0,05)$. Найбільші зміни значень показників ВСР порівняно з даними на початку курсу відмічені в період 6-7 доби.

Висновки. У комбатантів на етапі реабілітації первинним є стан ваготонії. Упродовж комплексної реабілітації адаптаційні зміни є найбільшими в період 3-7 доби від початку курсу, спостерігаються фазні коливання вегетативного балансу (спочатку в бік симпатикотонії, а пізніше в бік компенсації стану). Тривалість курсу ОП у складі комплексної реабілітації при дезадаптозах має становити 7-10 діб.

Ключові слова: варіабельність серцевого ритму, комбатанти, реабілітація, об’ємний пневмопресинг, автономна нервова система

\section{Вступ}

Перебування в зоні проведення АТО/ООС, участь у веденні бойових дій сприяе появі віддалених наслідків у вигляді соматичних, невротичних і психосоматичних розладів. Розробляються та впроваджуються програми ранньої й віддаленої комплексної психологічної, медичної та соціальної реабілітації учасників бойових дій (комбатантів), волонтерів, переселених осіб і членів їхніх сімей.
Пропонуються методи діагностики та оцінки ефективності цих програм. Триває вивчення розвитку наслідків бойової травми та їхніх окремих рис, обумовлених специфікою цього локального конфлікту.

При вивченні загальних змін функціонального стану автономної нервової системи (АНС) у комбатантів під час процедури об'ємного пневмопресингу (ОП) за даними варіабельності серцевого ритму 
ISSN 2223-6775, Ukrainian Journal of Occupational Health, 2019, 15 (2), 152-161

(BCP) та гемодинаміки було показано, що під час процедури ОП виявлявся релаксаційний ефект у вигляді зниження частоти серцевих скорочень (ЧСС) [1]. Статистично достовірні $(\mathrm{p}<0,05)$ зміни низки показників ВСР були розцінені як зростання парасимпатичного впливу та ролі сегментарної вегетативної регуляції. У разі порівняння комбатантів 3 умовно здоровими особами було виявлено, що динаміка майже всіх аналізованих показників ВСР у комбатантів наближалася до значень контрольної групи. Було сформульовано висновок, що застосована методика ОП сприяла зростанню активності та зменшенню напруженості регуляторних систем (розвитку автономізації та підвищеного впливу парасимпатичних центрів регуляції), зменшенню серцевого навантаження (зниженню систолічного артеріального тиску, ЧСС) [1]. В цілому в комбатантів після процедури ОП спостерігалося наближення показників артеріального тиску та ВСР до значень контрольної групи, що свідчило про відновлення функціонального стану.

Ці дослідження залишили відкритими питання щодо динаміки стану організму комбатантів упродовж курсу ОП.

Для оцінки отриманих даних було проведено аналіз доступних джерел літератури, у яких надано норми ВСР. Особливу складність як при клінічному розгляді індивідуального випадку, так і при аналізі статистичних даних становить оцінка отриманих значень відносно коридора функціональної норми. Це зумовлено наявністю певних протиріч між «нормативними» даними, наведеними різними авторами. Для ілюстрації труднощів, які виникають при цьому, порівняємо дані щодо нормальних значень деяких показників ВСР, наданих кількома авторами (за наявності в джерелах розподілу за віком обмежимось віковою групою від 20 до 60 років ) ( табл. 1).

\section{Нормальні значення деяких показників варіабельності серцевого ритму} за даними різних авторів, $M \pm \mathrm{m}$

\begin{tabular}{|c|c|c|c|c|}
\hline $\begin{array}{c}\text { Показник } \\
\text { варіабельності } \\
\text { серцевого ритму }\end{array}$ & $\begin{array}{l}\text { Р. М. Баєвський }[2,3] \text {, } \\
\text { А. М. Вейн [4] }\end{array}$ & $\begin{array}{c}\text { ESC, NASPE } \\
{[5]}\end{array}$ & А. П. Кулаїчев [6] & $\begin{array}{c}\text { М. І. Яблучанський [7] } \\
\text { (вдень) }\end{array}$ \\
\hline $\begin{array}{l}\text { Частота серцевих } \\
\text { скорочень (ЧСС), уд./хв }\end{array}$ & $\begin{array}{c}61-74, \\
\text { чол.: } 63 \pm 2(<25 \text { років }) \\
61 \pm 2(25-40 \text { років }) \\
70 \pm 2(>40 \text { років })\end{array}$ & - & - & $55-85$ \\
\hline $\mathrm{RR}, \mathrm{Mc}$ & $810 \pm 10$ & - & - & $\begin{array}{c}754 \pm 35 \\
(20-39 \text { років), } \\
832 \pm 19 \\
(40-59 \text { років) }\end{array}$ \\
\hline RRNN, mc & - & - & $\begin{array}{c}64,0 \pm 2,6 \\
(19-26 \text { років), } \\
74,0 \pm 4,1 \\
(31-49 \text { років) }\end{array}$ & - \\
\hline RMSSD, мс & - & $27 \pm 12^{*}$ & $33 \pm 17$ & $\begin{array}{c}32,2 \pm 2,9 \\
(20-39 \text { років }), \\
27,7 \pm 1,2 \\
(40-59 \text { років })\end{array}$ \\
\hline SDNN, мс & - & $141 \pm 39^{*}$ & $91 \pm 29$ & $\begin{array}{c}59,8 \pm 3,7 \\
(20-39 \text { років), } \\
51,6 \pm 1,7 \\
(40-59 \text { років) }\end{array}$ \\
\hline pNN50, \% & - & - & $7 \pm 2$ & $\begin{array}{c}9,8 \pm 2,4 \\
(20-39 \text { років), } \\
6,3 \pm 0,8 \\
(40-59 \text { років) }\end{array}$ \\
\hline
\end{tabular}


Закінчення табл. 1

\begin{tabular}{|c|c|c|c|c|}
\hline $\begin{array}{c}\text { Показник } \\
\text { варіабельності } \\
\text { серцевого ритму }\end{array}$ & $\begin{array}{l}\text { Р. М. Баєвський }[2,3] \text {, } \\
\text { А. М. Вейн [4] }\end{array}$ & $\begin{array}{c}\text { ESC, NASPE } \\
{[5]}\end{array}$ & А. П. Кулаїчев [6] & $\begin{array}{c}\text { М. І. Яблучанський [7] } \\
\text { (вдень) }\end{array}$ \\
\hline AMo, $\%$ & $\begin{array}{c}28,9 \pm 1,3 * \\
30-50 \\
\text { чол.: } 36 \pm 3(<25 \text { років }) \\
47 \pm 3(25-40 \text { років }) \\
32 \pm 3(>40 \text { років })\end{array}$ & - & $\begin{array}{c}<40 \\
(<25 \text { років; }+1 \% \\
\text { кожні } 5 \text { років } \\
\text { але } \leq 50 \%)\end{array}$ & - \\
\hline deltaX, mc & $\begin{array}{c}270 \pm 20^{*} \\
151-299 \\
\text { чол.: } 380 \pm 70(<25 \text { років }), \\
290 \pm 30(25-40 \text { років }) \\
280 \pm 60(>40 \text { років })\end{array}$ & - & - & - \\
\hline $\mathrm{IH}$, у. о. & $\begin{array}{c}51-199 \\
\text { чол.: } 67 \pm 10(<25 \text { років) } \\
112 \pm 22(25-40 \text { років }) \\
95 \pm 20(>40 \text { років })\end{array}$ & - & $\begin{array}{c}62,3 \pm 39,1 \\
(19-26 \text { років) }\end{array}$ & - \\
\hline $\mathrm{TP}, \mathrm{мc}^{2}$ & - & $3466 \pm 1018$ & - & $\begin{array}{c}>3000 \text { (висока*), } \\
\text { 1500-3000 (помірна*), } \\
\text { 300-1500 (низька*) }\end{array}$ \\
\hline VLF, $\mathrm{Mc}^{2}$ & - & - & - & $\begin{array}{c}1677 \pm 36 \\
(20-39 \text { років }), \\
1542 \pm 145 \\
(40-59 \text { років })\end{array}$ \\
\hline $\mathrm{LF}, \mathrm{mc}^{2}$ & - & $1170 \pm 416$ & - & $\begin{array}{c}810 \pm 92 \\
(20-39 \text { років), } \\
710 \pm 63 \\
(40-59 \text { років })\end{array}$ \\
\hline $\mathrm{HF}, \mathrm{Mc}^{2}$ & - & $975 \pm 203$ & - & $\begin{array}{c}540 \pm 98 \\
(20-39 \text { років }), \\
386 \pm 25 \\
(40-59 \text { років })\end{array}$ \\
\hline LFnorm, \% & - & $54 \pm 4$ & $50,6 \pm 9,4$ & $\begin{array}{c}59,8 \pm 2,2 \\
(20-39 \text { років }) \\
64,8 \pm 1,8 \\
(40-59 \text { років })\end{array}$ \\
\hline HFnorm, \% & - & $29 \pm 3$ & $49,4 \pm 9,4$ & $\begin{array}{c}40,1 \pm 2,2 \\
(20-39 \text { років), } \\
35,1 \pm 1,7 \\
(40-59 \text { років })\end{array}$ \\
\hline LF/HF, у. о. & - & $1,5-2,0$ & $0,7 \pm 1,5$ & $\begin{array}{c}1,3-1,9 \\
1,50 \pm 0,39 \\
(20-39 \text { років }) \\
1,83 \pm 0,2 \\
(40-59 \text { років) }\end{array}$ \\
\hline
\end{tabular}

Примітка. *Середньодобові дані, риска - немає даних, RRNN- середня довжина RR-інтервалу, RMSSD - квадратний корінь суми різниць послідовного ряду RR-інтервалів, SDNN - стандартне середнє відхилення повного масиву RR-інтервалів, pNN50 - відсоток послідовних пар RR-інтервалів, що відрізняються більш ніж на 50 мс, АМо - амплітуда моди, IH - індекс P. M. Баєвського напруження регуляторних систем, deltaX - варіаційний розмах, TP - сума потужностей спектра, $V L F$ - потужність дуже низькочастотного спектрального компоненту, LF - потужність низькочастотного спектрального компоненту, LFnorm - відношення LF до суми LF+HF; HF - потужність високочастотного спектрального компоненту, HFnоrm - відношення HF до суми LF + HF, LF/HF - індекс вагосимпатичної взаємодії. 
ISSN 2223-6775, Ukrainian Journal of Occupational Health, 2019, 15 (2), 152-161

3 наведених у таблиці 1 довідкових даних видно, що, попри багаторічне використання методу дослідження ВСР у багатьох країнах світу, уявлення щодо нормальних значень показників залишаються нечіткими. Вважається навіть, що для ВСР доцільно говорити лише про межі індивідуальної норми [7]. Тим не менше, з наведених норм найпридатнішими, на нашу думку, є дані М. І. Яблучанського і О. В. Мартиненка, оскільки, за наявною деталізацією, вони найближчі за умовами реєстрації ВСР до вимірювань, які здійснюються нами.

Мета дослідження - визначення напряму адаптаційних реакцій автономної нервової системи (у бік ваго-, нормо- чи симпатикотонії), що переважає у комбатантів АТО на етапі реабілітації, виявлення особливостей динаміки функціонального стану комбатантів упродовж курсу комплексної реабілітації та визначення за станом АНС строку найбільшої терапевтичної успішності реабілітаційного курсу в комбатантів.

\section{Матеріали та методи дослідження}

До дослідження за індивідуальною інформованою згодою були залучені комбатанти (учасники бойових дій в зоні проведення ООС), які отримували курс комплексної реабілітації в умовах стаціонару за протоколом відділу медико-психологічної реабілітації клініки професійний захворювань ДУ «Інститут медицини праці імені Ю. І. Кундієва
НАМН України» у 2016-2018 роках. Основну групу склали 41 чоловік віком 19-45 років. У більшості пацієнтів були діагностовані посттравматичний стресовий розлад, астено-невротичний синдром, наслідки перенесених контузій.

До складу комплексної реабілітації входила процедура ОП, яка проводилась за допомогою апарата «Біо-1» на зоні голови та спини впродовж 20 хв. Запис ВСР проводили за допомогою апарата «МПФИ ритмограф- $1 »[8]$ впродовж 5 хв, а саме: 1 раз перед процедурою (фонові дані), 4 рази під час процедури та 1 раз після процедури. Реєстрацію даних виконували 4 рази впродовж реабілітаційного курсу, а саме: перший замір у 1 добу реабілітаційного курсу, другий замір у 3-4 добу, третій замір у 6-7 добу, 4 замір у 10-11 добу. Статистичну обробку отриманих даних виконували методами варіаційної та непараметричної (критерій знаків) статистики за допомогою пакета програм STATISTICA 6.1.

\section{Результати дослідження та їх обговорення}

Для узагальненого визначення напряму адаптаційних реакцій АНС, що переважає в комбатантів на етапі реабілітації, було проаналізовано фонові дані ВCР, зареєстровані перед процедурою ОП. Також проводилась реєстрація артеріального тиску з розрахунком індексу Кердо. Результати надано в таблиці 2. Межі нормальних значень надані за I. Kérdö [9] (індекс Кердо), М. І. Яблучанським

Адаптаційні реакції автономної нервової системи в комбатантів АТО на етапі реабілітації

\begin{tabular}{|l|c|c|c|c|c|}
\hline \multirow{2}{*}{\multicolumn{1}{c|}{ Показник }} & \multirow{2}{*}{ Норма } & M \pm m & \multicolumn{3}{c|}{ Випадок, \% } \\
\cline { 4 - 6 } & & & ваготонія & нормотонія & симпатикотонія \\
\hline Iндекс Кердо, у. о. & $-15-15$ & $-18,6 \pm 1,8$ & $56,1 \pm 0,3^{*}$ & $37,8 \pm 0,3$ & $6,1 \pm 0,1$ \\
\hline SDNN, мс & $49,9-63,5$ & $42,9 \pm 1,6$ & $69,4 \pm 0,2^{*}$ & $10,1 \pm 0,2$ & $20,5 \pm 0,2$ \\
\hline RMSSD, мс & $26,5-35,1$ & $33,8 \pm 2,1$ & $48,3 \pm 0,3^{*}$ & $17,4 \pm 0,2$ & $34,4 \pm 0,2$ \\
\hline AMo, \% & $31-49$ & $49,6 \pm 1,1$ & $49,1 \pm 0,3$ & $10,4 \pm 0,2$ & $40,6 \pm 0,3$ \\
\hline deltaX, мс & $160-290$ & $254,6 \pm 8,2$ & $26,4 \pm 0,2^{*}$ & $35,8 \pm 0,2$ & $37,7 \pm 0,2$ \\
\hline IBP, 1/c & $100-300$ & $252,0 \pm 11,8$ & $17,5 \pm 0,2^{*}$ & $51,0 \pm 0,3$ & $31,4 \pm 0,2$ \\
\hline LF, мc ${ }^{2}$ & $649-902$ & $381,8 \pm 26,9$ & $79,3 \pm 0,2^{*}$ & $11,9 \pm 0,2$ & $8,8 \pm 0,1$ \\
\hline
\end{tabular}

Примітка. *Статистично достовірна відмінність між випадками ваготонії та симпатикотонії ( $p<0,05$ за t-критерієм Cтьюдента), SDNN - стандартне середнє відхилення повного масиву RR-інтервалів, RMSSD - квадратний корінь суми різниць послідовного ряду RR-інтервалів, АMо - амплітуда моди, deltaX - варіаційний розмах, IВP - індекс вегетативної рівноваги, LF - потужність низькочастотного спектрального компоненту. 
(SDNN, RMSSD, LF) [7] та P. M. Баєвським (AMо, deltaX) [2].

Наведені дані дозволяють говорити про те, що в комбатантів, які отримують реабілітаційну допомогу в зв'язку з посттравматичним стресовим розладом (ПТСР) та розладами адаптації, в цілому переважає стан ваготонії. Причиною виявленого явища може бути те, що пацієнти вийшли з психотравмуючої, стресової обстановки й знаходяться в сприятливому середовищі, спокійному оточенні, у ситуації відновлювального лікування.

Для оцінки загальної динаміки функціонального стану АНС впродовж курсу реабілітації були проаналізовані усереднені значення показників BCP, які характеризують вегетативний баланс (RMSSD, pNN50, Moda, AMo, deltaX, IH, SDNN і сума потужностей спектра) та централізацію управління серцевим ритмом (IH).

При інтерпретації отриманих даних була врахована висока чутливість методу дослідження ВСР до адаптаційних процесів, які безупинно реагують на зовнішній вплив. Було зроблено припущення про те, що за фізіологічним змістом записи ВСР можна умовно віднести до двох категорій: фонові дані (у стані спокою) відображають інтегральну дію реабі- літаційних факторів, а дані, записані під час проведення процедури ОП та безпосередньо після неї, відображають ту саму інтегральну дію з накладенням (акцентуванням) впливу процедури ОП. Для оцінки правомірності цього припущення була порівняна курсова динаміка фонового стану (табл. 3) і загального стану АНС (табл. 4).

При порівнянні даних таблиць 3 і 4 були виявлені достовірні відмінності значень окремих показників ВСР, які свідчать про правомірність трактовки фонових даних ВСР як відображення дії реабілітації в цілому, а даних, записаних під час процедури ОП, як відображення дії процедури ОП на тлі комплексної реабілітації.

Для оцінки загальної динаміки функціонального стану АНС впродовж курсу реабілітації були проаналізовані дані, отримані до, під час і після процедур ОП. Тому наведена у таблиці 4 динаміка показників ВСР, імовірно, характеризуе більшою мірою дію комплексної реабілітації в цілому, а їхні конкретні значення зумовлені переважно впливом процедур ОП.

Під час курсу спостерігаються статистично достовірні зменшення pNN50 і Moda; ріст AMo, IH, IBP та ВПР; відсутність росту RMSSD. В ціло-

Таблшц 3

Фоновий стан автономної нервової системи впродовж курсу комплексної реабілітації, $\mathrm{M} \pm \mathrm{m}$

\begin{tabular}{|c|c|c|c|c|}
\hline \multirow{2}{*}{$\begin{array}{c}\text { Показник варіабельності } \\
\text { серцевого ритму }\end{array}$} & \multicolumn{4}{|c|}{ Номер заміру } \\
\hline & $1, n=38$ & $2, n=35$ & $3, n=19$ & $4, n=13$ \\
\hline RMSSD, мс & $42,69 \pm 5,01$ & $35,92 \pm 5,68$ & $25,44 \pm 2,78^{* *}$ & $28,83 \pm 5,17$ \\
\hline pNN50, \% & $17,90 \pm 3,31$ & $11,74 \pm 2,35$ & $7,20 \pm 1,86^{* *}$ & $8,33 \pm 3,35$ \\
\hline Moda, mc & $943,4 \pm 23,2$ & $875,0 \pm 22,3$ & $859,2 \pm 33,3$ & $855,8 \pm 42,9$ \\
\hline AMo, $\%$ & $46,17 \pm 2,66$ & $47,09 \pm 2,55$ & $51,80 \pm 4,03^{*}$ & $50,39 \pm 3,33$ \\
\hline IBP, $1 / \mathrm{c}$ & $225,4 \pm 29,0$ & $229,1 \pm 27,1^{*}$ & $294,4 \pm 49,9 * *$ & $250,8 \pm 36,1$ \\
\hline ВПР, $1 / \mathrm{c}^{2}$ & $4,757 \pm 0,427$ & $5,157 \pm 0,430$ & $6,285 \pm 0,739 * *$ & $5,782 \pm 0,665$ \\
\hline deltaX, мс & $288,2 \pm 22,1$ & $277,1 \pm 22,3$ & $228,9 \pm 22,1^{*}$ & $234,6 \pm 21,5$ \\
\hline IH, y. o. & $125,8 \pm 17,3$ & $137,4 \pm 18,0$ & $183,2 \pm 37,0 * *$ & $156,0 \pm 26,5$ \\
\hline SDNN, мс & $48,95 \pm 4,09$ & $46,04 \pm 4,03$ & $37,77 \pm 3,98^{* *}$ & $39,47 \pm 4,63$ \\
\hline $\mathrm{TP}, \mathrm{Mc}^{2}$ & $1458 \pm 220^{*}$ & $1291 \pm 196$ & $968 \pm 193$ & $992 \pm 210$ \\
\hline
\end{tabular}

Примітка. Відмінність середніх значень фонових від загальних достовірна на рівні ${ }^{*} p<0,1$, та ** $p<0,05$ за критерієм знаків, RMSSD - квадратний корінь суми різниць послідовного ряду RR-інтервалів, pNN50 - відсоток послідовних пар $R R$-інтервалів, що відрізняються більш ніж на 50 мс, Moda - значення, що найчастіше зустрічається, RR-інтервалів, які відповідають найвірогіднішому рівню функціонування систем регуляції, АМо - амплітуда моди, IBP - індекс вегетативної рівноваги, ВПР - вегетативний показник ритму, deltaX - варіаційний розмах, IH - індекс Р. М. Баєвського напруження регуляторних систем, SDNN - стандартне середнє відхилення повного масиву RR-інтервалів, TP - сума потужностей спектра. 
ISSN 2223-6775, Ukrainian Journal of Occupational Health, 2019, 15 (2), 152-161

Таблщц 4

Загальний стан автономної нервової системи впродовж курсу комплексної реабілітації, $\mathrm{M} \pm \mathrm{m}$

\begin{tabular}{|c|c|c|c|c|}
\hline \multirow{2}{*}{$\begin{array}{c}\text { Показник варіабельності } \\
\text { серцевого ритму }\end{array}$} & \multicolumn{4}{|c|}{ Номер заміру } \\
\hline & $1, n=229$ & $2, n=211$ & $3, n=121$ & $4, n=76$ \\
\hline RMSSD, мс & $41,4 \pm 2,08$ & $37,48 \pm 2,41$ & $30,48 \pm 2,15^{*}$ & $27,89 \pm 1,95^{*}$ \\
\hline pNN50, \% & $16,97 \pm 1,33$ & $13,06 \pm 1,11$ & $10,37 \pm 1,20$ & $8,33 \pm 1,31^{*}$ \\
\hline Moda, Mc & $937,9 \pm 10,1$ & $881,2 \pm 9,5^{*}$ & $856,8 \pm 12,7^{*}$ & $850,7 \pm 16,3^{*}$ \\
\hline AMo, $\%$ & $43,27 \pm 0,98$ & $45,65 \pm 0,98$ & $50,97 \pm 1,49^{*}$ & $47,96 \pm 1,51$ \\
\hline IBP, $1 / \mathrm{c}$ & $206,3 \pm 9,9$ & $217,6 \pm 10,1$ & $291,8 \pm 23,1^{*}$ & $232,7 \pm 15,9$ \\
\hline ВПР, $1 / \mathrm{c}^{2}$ & $4,742 \pm 0,159$ & $5,081 \pm 0,170$ & $6,276 \pm 0,366^{*}$ & $5,534 \pm 0,268$ \\
\hline deltaX, Mc & $285,8 \pm 8,8$ & $279,1 \pm 8,8$ & $245,5 \pm 10,5$ & $255,9 \pm 12,2$ \\
\hline IH, у. о. & $116,7 \pm 6,1$ & $130,3 \pm 6,6$ & $185,2 \pm 17,1^{*}$ & $144,9 \pm 10,7$ \\
\hline SDNN, мс & $51,48 \pm 1,80$ & $49,21 \pm 1,82$ & $41,31 \pm 2,01$ & $43,58 \pm 2,58$ \\
\hline ТP, $\mathrm{Mc}^{2}$ & $1641 \pm 120$ & $1529 \pm 109$ & $1158 \pm 109$ & $1281 \pm 163$ \\
\hline
\end{tabular}

Примітка. *Відмінність середніх значень від 1 заміру достовірна на рівні $p<0,05$ за t-критерієм Cтьюдента, RMSSD квадратний корінь суми різниць послідовного ряду RR-інтервалів, pNN50 - відсоток послідовних пар RR-інтервалів, що відрізняються більше ніж на 50 мс, Мода - значення, що найчастіше зустрічається, RR-інтервалів, які відповідають найвірогіднішому рівню функціонування систем регуляції, АМо - амплітуда моди, IВР - індекс вегетативної рівноваги, ВПР - вегетативний показник ритму, deltaX - варіаційний розмах, IH - індекс $P$. М. Баєвського напруження регуляторних систем, SDNN - стандартне середнє відхилення повного масиву RR-інтервалів, TP - сума потужностей спектра.

му такі зміни можуть характеризувати зміщення вегетативного балансу в бік симпатикотонії.

Статистично достовірний ріст ІН відбувається в межах норми (за Р. М. Баєвським [2]) і може вказувати на активне протікання адаптаційних процесів в організмі впродовж курсу.

Важливо відмітити, що, хоча статистично достовірна відмінність функціонального стану комбатантів від зареєстрованого під час 1 заміру спостерігається вже під час 2 заміру, найбільша кількість показників, значення яких статистично достовірно змінилося порівняно з 1 заміром, відмічається в період 3 заміру (6-7 доба курсу). Надалі досягнуті відмінності функціонального стану від початкового виражені менше.

Хоча базовим станом у комбатантів $€$ переважно ваготонія, зсув у бік симпатикотонії з огляду на діагностований у більшості пацієнтів стан хронічного стресу потребує відповіді на запитання: чи можна таку динаміку оцінювати як погіршення функціонального стану, чи як його нормалізацію? Для аналізу були відібрані такі показники ВСР, які характеризують вегетативний баланс, і для яких є межі норми за М. І. Яблучанським і О. В. Мартиненком [7]. Надалі для порівняння з нормою індивідуальні дані, отримані від пацієнта за кожен замір, були усереднені для мінімізації можливих ситуаційних артефактів. Було оцінено наявність зсуву в динаміці середніх значень відповідних показників у кожного пацієнта - зростання чи зниження від одного заміру до наступного. При цьому аналізувалися всі наявні дані, а не лише чотири «маркерні» заміри, які описані в даній роботі (тобто, не лише 1, 4, 7 i 10 доба курсу), оскільки тривалість курсу була різна й не в усіх пацієнтів можна обмежитись оцінкою різниці стану між початком і кінцем курсу. Нарешті, були підраховані випадки зниження та росту занижених і завищених показників ВСР у всій вибірці (рисунок).

Усього за аналізованими показниками ВСР упродовж реабілітаційного курсу відмічено 280 випадків з 625 проб $(44,8 \pm 0,1) \%)$ нормалізації функціонального стану та 154 випадки $(24,6 \pm$ $0,1) \%$ ) посилення наявних відхилень від меж норми. Відмінність між відсотком випадків нормалізації та погіршення функціонального стану статистично достовірна на рівні $p<0,05$. Відмічається також 55 випадків $(8,8 \pm 0) \%)$ виходу усереднених значень вищенаведених показників ВСР за межі норми («поява погіршень») і 136 випадків $(21,8 \pm 0,1) \%$ ) 


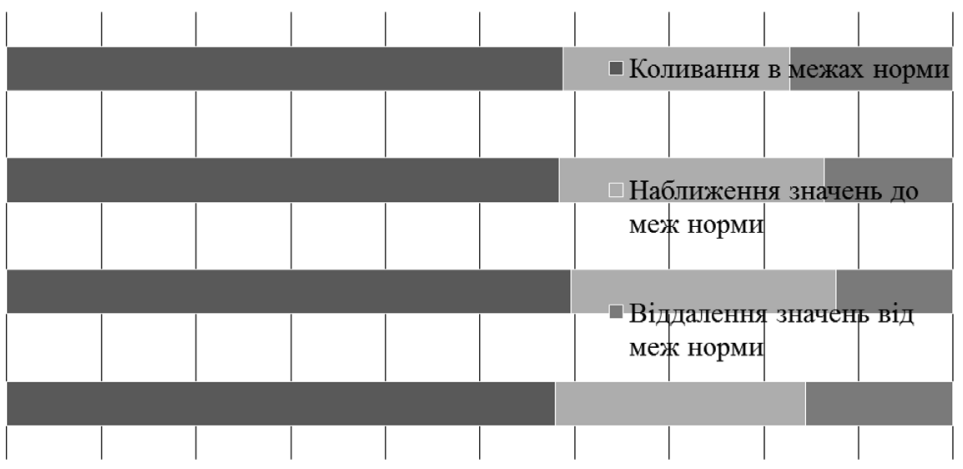

Рисунок. Відсоток комбатантів, у яких реабілітаційні заходи сприяють наближенню та відхиленню від норми Примітка. Відмінність між відсотками випадків нормалізації та погіршення функціонального стану достовірна відповідно: ${ }^{*}$ на рівні $p<0,1,{ }^{* *}$ на рівні $p<0,05$ за t-критерієм Стьюдента. коливань значень у межах норми. Втім, динаміка показників за типом нормалізації навіть у цьому випадку статистично достовірно превалює в комбатантів $(44,8 \pm 0,1) \%$ проти $(33,4 \pm 0,1) \%, p<0,05)$.

Узагальнюючи характеристику вегетативного балансу в комбатантів на етапі реабілітації, можна сказати, що вихідним є переважно стан ваготонії, який під дією чинників комплексної реабілітації змінюється адаптаційною фазою симпатикотонічної реакції, і в цілому завершується виникненням компенсованого, близького до норми, стану, про що свідчить гармонізація вегетативного балансу.

Для оцінки реактивності організму комбатантів були порівняні усереднені значення показників ВСР, зареєстровані перед процедурою ОП і після процедури. Достовірні на рівні р < 0,05 за критерієм знаків зміни різниці середніх впродовж курсу відмічалися лише під час другого заміру, а саме: стандартне середне відхилення повного масиву $\mathrm{RR}$-інтервалів (SDNN) зросло на $(28,5 \pm 1,1) \%$; варіаційний розмах (deltaX) зріс на $(16,8 \pm 1,0) \%$; вегетативний показник ритму знизився на (18,6 \pm $1,2)$ \%; показник адекватності процесів регуляції знизився на $(16,3 \pm 1,1) \%$; індекс дихальної модуляції (за А. Я. Қапланом) зріс на (12,8 \pm 0,9) \%; індекс симпато-адреналового тонусу (за А. Я. Капланом ) знизився на $(21,3 \pm 1,2) \%$; сума потужностей спектра зросла на $(78,8 \pm 1,4) \%$; потужність дуже низькочастотного спектрального компоненту зросла на $(69,4 \pm 1,3) \%$; потужність низькочастотного спектрального компоненту зросла на $(94,0 \pm 1,4) \%$; потужність високочастотного спектрального компоненту зросла на $(75,4 \pm$ $1,4) \%$. Отже, статистично достовірні (на рівні $\mathrm{p}<$ 0,05 за критерієм знаків) зміни значень показників ВСР у результаті процедури ОП спостерігалися тільки під час 2 заміру - 10 показників з 14 - в інші ж періоди курсу динаміка змін, викликаних процедурою ОП, за жодним з показників не досягала статистичної значущості. Тобто, максимум адаптаційних реакцій, період найбільшої реактивності організму за даними ВСР спостерігалася в період близько 4 доби від початку курсу реабілітації. Попереднім аналізом (табл. 3) було також показано, що найбільші відмінності між фоновим станом і його змінами під впливом процедури ОП реєструються під час 3 заміру (6-7 доба). Це свідчить про те, що вплив реабілітаційного процесу на організм відбувається гетерохромно, характеризується адаптаційними змінами фаз ваготонії та симпатикотонії. Стосовно практичних рекомендацій це може означати, що тривалість курсу ОП у разі даної методики у складі комплексної реабілітації за станів хронічного стресу та розладах адаптації для досягнення компенсованого стану має становити не менше ніж 7 діб.

\section{Висновки}

1. У комбатантів у період формування віддалених наслідків перенесеного бойового стресу первин ним на етапі реабілітації є стан ваготонії.

2. Найвища інтенсивність адаптаційних перетворень в організмі комбатантів спостерігається в період 3-7 доби від початку курсу медичної реабілітації.

3. Під час курсу комплексної реабілітації з залученням ОП спостерігається фазність адаптаційних перетворень показників, спочатку в бік симпатикотонії, а потім у бік нормалізації (компенсації) стану, розвиток якої відбувається в період близько 7 доби від початку використання процедури ОП в програмі курсу.

4. Для досягнення компенсованого стану за хронічного стресу та розладів адаптації тривалість курсу ОП у складі комплексної реабілітації має становити 7-10 діб. 
ISSN 2223-6775, Ukrainian Journal of Occupational Health, 2019, 15 (2), 152-161

\section{Література}

1. Зайцев Д. В., Кальниш В. В., Пишнов Г. Ю. Ефективність застосування методу об’ємного пневмопресингу під час реабілітації учасників антитерористичної операції. Украӥнський журнал з проблем медицини праці. 2017. № 2 (51). С. 46-54. https://doi.org/10.33573/ujoh2017.02.046.

2. Баевский Р. М. Прогнозирование состояний на грани нормы и патологии. Москва : Медицина, 1979. 298 c.

3. Баевский Р. М., Кириллов О. И., Клецкин С. 3. Математический анализ изменений сердечного ритма при стрессе. Москва : Наука, 1984. 221 с.

4. Вегетативные расстройства: клиника, лечение, диагностика; под ред. А. М. Вейна. Москва : Медицинское информационное агентство, 2000. С. 62.

5. Task Force of the European Society of Cardiology and the North American Society of Pacing and Electrophysiology. Heart Rate Variability. Standards of
Measurement, Physiological Interpretation and Clinical Use. Circulation. 1996. V. 93. P. 1043-1065. https://doi. org/10.1161/01.CIR.93.5.1043.

6. Кулаичев А. П. Компьютерная электрофизиология и функциональная диагностика. 4-е изд., перераб. и доп. Москва : ИНФРА-М, 2007. С. 370-389.

7. Яблучанский Н. И., Мартыненко А. В. Вариабельность сердечного ритма. В помощь практическому врачу. Для настоящих врачей. Харьков, 2010. C. 54,68 .

8. Кочина М. Л., Каминский А. А., Маленкин В. А. Информационная технология прогноза функционального состояния сердечно-сосудистой системы. Кибернетика и вычислительная техника. Вып. 170. 2012. C. 15-27.

9. Kérdö I. Ein aus Daten der Blutzirkulation kalkulierter Index zur Beurteilung der vegetativen Tonuslage. Acta Neurovegetativa. 1966. № 2. S. 250268. https://doi.org/10.1007/BF01269900.

\section{Зайиев А. В.}

\section{ОСОБЕННОСТИ АИНАМИКИ ФУНКИИОНААЬНОГО СОСТОЯНИЯ КОМБАТАНТОВ С ПОСАЕАСТВИЯМИ БОЕВОГО СТРЕССА ПО ПОКАЗАТЕАЯМ ВАРИАБЕАЬНОСТИ СЕРАЕЧНОГО РИТМА В ПРОЧЕССЕ КУРСА КОМПАЕКСНОЙ РЕАБИАИТАЧИИ}

Государственное учрежАение «Институт медишины труда имени Ю. И. Кундиева Нашиональной академии медишинских наук Украины», г. Киев

Введение. Одним из предложенных методов реабилитации участников боевых действий является объемный пневмопрессинг (ОП). Процедура ОП способствует росту активности и уменьшению напряженности регуляторных систем (развитию автономизации и росту влияния парасимпатических центров), уменьшению сердечной нагрузки, восстановлению функционального состояния. Однако динамика состояния организма в течение курса ОП требует дальнейшего изучения.

Цель исследования - выявить особенности динамики функционального состояния комбатантов в течение курса комплексной реабилитации, определить по состоянию автономной нервной системы срок наибольшей терапевтической успешности реабилитационного курса.

Материалы и методы исследования. К исследованию на основе информированного согласия привлекались участники боевых действий в зоне проведения АТО/ООС (41 человек в возрасте 19-45 лет), получавшие курс комплексной реабилитации, в частности, процедуры ОП на зоне головы и спины в течение 20 мин, в связи с диагностированными расстройствами адаптации. Запись вариабельности сердечного ритма (ВСР) проводилась в течение 5 мин: 1 раз перед процедурой, 4 раза во время процедуры и 1 раз после процедуры. Замеры выполнялись 4 раза (1 сутки реабилитационного курса, 3-4 сутки, 6-7 сутки и 10-11 сутки). Статистическая обработка выполнялась методами вариационной и непараметрической статистики.

Результаты. По данным ВСР для комбатантов с расстройствами адаптации характерно состояние ваготонии. В течение курса комплексной реабилитации отмечаются колебания индекса напряжения Баевского, что характерно для активных адаптационных процессов. Наблюдается статистически достоверное смещение вегетативного баланса в сторону симпатикотонии, что можно оценивать как нормализацию (компенсацию) функционального состояния. В течение реабилитационного курса отмечено 44,8 \% случаев нормализации функционального состояния и 33,4 \% случаев усиления отклонений от границ нормы. Динамика показателей по типу нормализации превалирует ( $<0,05)$. При оценке реактивности организма комбатантов под действием процедуры ОП выявлено, что наибольшие кратковременные изменения функционального состояния (максимум адаптационных реакций) наблюдались в период около 4 суток от начала курса реабилитации (р < 0,05). Наибольшие изменения значений показателей ВСР по сравнению с данными в начале курса отмечены в период 6-7 суток.

Bыводы. У комбатантов на этапе реабилитации первичным является состояние ваготонии. В процессе комплексной реабилитации наибольше адаптационные изменения характерны для периода 3-7 суток от начала курса, 
наблюдаются фазные колебания вегетативного баланса (в сторону симпатикотонии, а позже в сторону компенсации состояния). Продолжительность курса ОП в составе комплексной реабилитации при дезадаптозах должна составлять $7-10$ суток.

Ключевые слова: вариабельность сердечного ритма, комбатанты, реабилитация, объемный пневмопрессинг, автономная нервная система

\title{
Zaitsev D. V. \\ DYNAMICS OF THE FUNCTIONAL STATE OF COMBATANTS WITH CONSEQUENCES OF THE BATTLE STRESS BY INDICATORS OF HEART RHYTHM VARIABILITY IN THE COURSE OF COMPLEX REHABILITATION
}

\author{
State Institution «Kundiiev Institute of Occupational Medicine of the National Academy of Medical Sciences \\ of Ukraine», Kyiv
}

Introduction. One of the proposed methods for rehabilitation of combatants is volumetric pneumopressing (VP). The VP procedure increases activity and decreases the tension of the regulatory systems (promotes the development of autonomy and influence of parasympathetic centers), decreases a cardiac load, and restore the functional state. However, the dynamics of the body state in the course of VP requires further study.

The purpose was to identify peculiarities of the functional state of combatants in the course of the complex rehabilitation, to define a period of the greatest therapeutic success in the rehabilitation course by the state of the autonomic nervous system.

Materials and methods. The results of the research activities of the laboratory in the main scientific areas. 41 combatants with adaptative disorders, engaged in the anti-terrorist operation (aged 19-45), took part in the investigarion after giving the informed consent. They received a course of complex rehabilitation with the VP procedure in the area of head and back for $20 \mathrm{~min}$. The heart rate variability (HRV) was recorded for $5 \mathrm{~min}$ : first time - before the procedure, four times - during it and once after it. The measurements were made four times (on the 1 st day of the course, on the $3^{\text {rd }}-4^{\text {th }}$ days, $6^{\text {th }}-7^{\text {th }}$ days and $10^{\text {th }}-11^{\text {th }}$ days). The variation and non-parametric statistics were used.

Results. The state of vagotonia was characteristics for combatants with adaptation disorders by the data of the HRV. Fluctuations of indices in the stress index by Bayevsky were recorded, being typical for adaptation processes. There was a statistically significant shift in the vegetative balance towards sympathetic activity, which could be assessed as normalization (compensation) of the functional state. $44,8 \%$ cases of the functional normalization and 33,4 \% cases of the increased deviations from the boundaries of the norm were recorded in the course of the rehabilitation. So, the normalization dynamics was prevailing $(\mathrm{p}<0,05)$. When assessing the biological reactivity in the combatants under the action of the VP procedure, the greatest short-term functional changes (maximum of adaptation reactions) were found after 4 days from the beginning of the course $(p<0,05)$. The greatest changes in indices of the HRV in comparison with the data at the beginning of the course were recorded after 6-7 days.

Conclusion. Vagotonia was the primary state in combatants in the process of rehabilitation. The main adaptive changes are observed on the $3^{\text {rd }}-7^{\text {th }}$ days from the beginning of the complex rehabilitation course. There were observed fluctuations in the vegetative balance towards compensation of the state. The duration of the VP procedure as a part of the complex rehabilitation in treatment of adaptation disorders should be 7-10 days.

Key words: heart rate variability, combatants, rehabilitation, volumetric pneumopressing, autonomic nervous system

\section{References}

1. Zaitsev D. V., Kalnish V. V., Pyshnov G. Yu. (2017), «Effectiveness evaluation of applying the volumetric pneumopressing for ATO participants in rehabilitation period", Ukrainian Journal of Occupational Health, 2 (51), 46-54. https://doi.org/10.33573/ujoh2017.02.046.

2. Bayevskij R. M. (1979), Prognozirovanie sostoyanij na grani normy i patologii [Forecasting states on the verge of the norm and pathology], Meditsina, Moscow, Russia.

3. Bayevskij R. M., Kirillov O. I. and Kletskin S. Z. (1984), Matematicheskij analiz izmenenij serdechnogo ritma pri stresse [Mathematical analysis of changes in the heart rate in the stress], Nauka, Moscow, Russia.
4. Vejn A. M. (ed.) (2000), Vegetativnye rasstrojstva: Klinika, lechenie, diagnostika [Vegetative disorders: Clinic, treatment, diagnosis], Meditsinskoe informatsionnoe agentstvo, Moscow, Russia.

5. Task Force of the European Society of Cardiology and the North American Society of Pacing and Electrophysiology (1996), "Heart Rate Variability. Standards of Measurement, Physiological Interpretation and Clinical Use», Circulation, 93, 1043-1065. https:// doi.org/10.1161/01.CIR.93.5.1043.

6. Kulaichev A. P. (2007), Kompyuternaya elektrofiziologiya i funktsionalnaya diagnostika [Computer electrophysiology and functional diagnostics], $4^{\text {th }}$ ed., INFRA-M, Moscow, Russia. 
ISSN 2223-6775, Ukrainian Journal of Occupational Health, 2019, 15 (2), 152-160

7. Yabluchanskij N. I. and Martynenko A. V. (2010), Variabelnost serdechnogo ritma. V pomosch prakticheskomu vrachu. Dlya nastoyaschikh vrachej [Heart rate variability. Helping the practitioner. For real doctors], Kharkiv, Ukraine.

8. Kochina M. L., Kaminskij A. A. and Malenkin V. A. (2012), "Information technology for prognosing the functional state of the cardiovascular system", Cybernetics and Computer Engineering, 170, 15-27.

9. Kérdö I. (1966), «Ein aus Daten der Blutzirkulation kalkulierter Index zur Beurteilung der vegetativen Tonuslage», Acta Neurovegetativa, 29, 250-268. https:// doi.org/10.1007/BF01269900.

\section{ORCID ID aвтора:}

Зайцев Д. В. (ORCID ID 0000-0002-0841-1504).

Інформація щздо джерел фінансування дослідження: дослідження виконано за темою «Встановити психофізіологічні закономірності змін розумової працездатності учасників АТО в процесі реабілітації» (№ 0116U000449).

Надійшла: 22 лютого 2019 р.

Прийнята до друку: 29 березня 2019 р.

Контактна особа: Зайцев Дмитро Валерійович, лабораторія психофізіології праці, ДУ «Інститут медицини праці імені Ю. І. Кундієва НАМН України», буд. 75, вул. Саксаганського, м. Київ, 01033. Тел.: + 380442894605. Електронна пошта: suhanovik@gmail.com 